Saudi Journal of Economics and Finance

Abbreviated Key Title: Saudi J Econ Fin

ISSN 2523-9414 (Print) | ISSN 2523-6563 (Online)

Scholars Middle East Publishers, Dubai, United Arab Emirates

Journal homepage: http://saudijournals.com

Original Research Article

\title{
Analysis of the Role of Village Personnel in Efforts Community Empowerment
} Dedi Nurmadi $^{1 *}$, Andi Tenri Sompa ${ }^{1}$, Muhammad Riduansyah Syafari ${ }^{1}$

${ }^{1}$ Masters in Development Administration, Postgraduate Program, Lambung Mangkurat University, Banjarmasin, Indonesia

DOI: $10.36348 /$ sjef.2021.v05i02.007 $\quad$ | Received: 10.02 .2021 | Accepted: 22.02 .2021 | Published: 26.02 .2021

*Corresponding author: Dedi Nurmadi

\section{Abstract}

This study aims to analyze and describe the role of village officials in empowering village communities in Sungai Asam Village, Karang Intan District, and Banjar Regency. This study used a qualitative descriptive approach and used data analysis techniques such as data reduction, data presentation, and data verification. The data used in this study are primary data and secondary data. The data collection techniques used in this study was interviews and documentation. While the instruments used in this study were structured interview guidelines and documents. The unit of analysis for this research is the role of village officials as the person in charge of managing village funds in Sungai Asam Village, Karang Intan District, Banjar Regency. The informants used in this study were the village head of Sungai Asam and the community who were the subject or objects of empowerment. This research was conducted in Sungai Asam Village, Karang Intan District, Banjar Regency. The results showed that the role of village officials in this case the village head in community empowerment efforts was already good. This can be seen from the good running of the village fund program and the positive response from the village community to the performance of the village head.

Keywords: Analysis, village apparatus, and empowerment.

Copyright ( $\odot$ 2021 The Author(s): This is an open-access article distributed under the terms of the Creative Commons Attribution 4.0 International License (CC BY-NC 4.0) which permits unrestricted use, distribution, and reproduction in any medium for non-commercial use provided the original author and source are credited.

\section{INTRODUCTION}

Law Number 6 of 2014 concerning villages has mandated village funds of around one billion for 74,958 villages throughout Indonesia to develop villages. The existence of this village fund is expected to provide opportunities for rural communities to develop their villages while changing their perspective that development only takes place in urban areas. So far, the disbursement of village funds has helped to reduce the number of underdeveloped villages. The data and information technology center of the village ministry in 2017 found that the number of underdeveloped villages fell 17 percent to 7,941, the number of developing villages increased by 10 percent to 58,313 villages, and independent villages increased by 7 percent to 7,839 villages. Although it should be noted that the size of the village development index is only physically easy to see and has not yet touched the aspects of government capacity and capacity, quality of democracy, and empowerment capacity.

After three years running, some villages have succeeded in utilizing the Village Fund effectively to take some innovative steps to independently solve various problems of village development with ideas and efforts that come from the community and village government. Through Law No.6 of 2014 concerning villages, villages have a great opportunity to take care of their governance and implementation of development to improve the welfare and quality of life of the community. Also, the village government is expected to be more independent in managing the government with its various natural resources, including financial management and village property. Such a large role that is accepted by the village, of course, is accompanied by a large responsibility. Therefore, the village government must be able to apply the principle of accountability in its governance. Where all the activities of implementing village government can be accounted for following the provisions. Government Regulation Number 60 of 2014 defines village funds as funds sourced from the state revenue and expenditure budget for villages that are transferred through the district/city regional income and expenditure budget. Village funds are a supply from the Government as a means of support for community development and empowerment and as a facility in developing and advancing the productivity of a village.

Sungai Asam Village is located in Karang Intan District, Banjar Regency. This village is one of 26 villages in the Karang Intan District area. Based on 
Dedi Nurmadi et al., Saudi J Econ Fin, Feb, 2021; 5(2): 76-79

the results of interviews and observations conducted by researchers to the Head of Sungai Asam Village, Mr. Abdussalam said that Sungai Asam Village had been successful in efforts to manage village fund finances, especially related to the empowerment of village communities and village administration. Based on the results of the literature review conducted by researchers, there is a difference in the assumption that the role of village officials has not been maximal in terms of empowering village communities, especially regarding village fund management. This has become a special attraction for researchers to further investigate the role of village officials in community empowerment efforts. The area of community empowerment that is the focus of this research is based on data from the Sungai Asam APBDes for the 2019 fiscal year amounting to IDR 22,500,000 (twenty-two million five hundred thousand rupiahs) consisting of Village Apparatus Capacity Building activities, PKPKD / PPKD / TPBJ Capacity Building activities, and Stunting Training / Counseling activities. Based on document research, the management of village funds in Sungai Asam Village, Karang Intan District is well managed according to the technical guidelines set by the Ministry of Village and PDTT and is a success for the village head and his staff in managing the village funds. However, based on field monitoring and reflecting on the social conditions in Sungai Asam village, there is a need for better management of village funds, especially in the allocation of village funds in the field of community empowerment. A better allocation of funds in the field of community empowerment is expected to be able to increase human resources in Sungai Asam village, which is still low. Based on the description above, the authors are interested in knowing more about village funds implemented in Sungai Asam Village, Karang Intan District by raising a research topic entitled "Analysis of the Role of Village Officials in Community Empowerment Efforts (Study on the Management of Dana Desa Sungai Asam in Karang Intan District. Intan, Banjar Regency)".

\section{RESEARCH METHOD}

This research uses a descriptive qualitative approach. Qualitative descriptive research uses qualitative methods to explore meanings, various variations, and perceptual understandings that lead to the emergence of the phenomena being studied [1]. The data analysis techniques used in this study were data reduction, data presentation, and data verification. Data reduction is to summarize select main things and focus on important things which are then presented in the form of a brief description and chart of the relationship between categories which is then carried out by data verification. Drawing conclusions in this study was carried out by analyzing the inductive approach which is a new and unprecedented finding. The data used in this study are primary data and secondary data. Primary data is data obtained from the first source. Meanwhile, secondary data is data obtained second-hand. The data collection techniques used in this study was interviews and documentation. Interviews by conducting direct face-to-face questions and answers with authorized parties in providing data and information needed for research are used to collect primary data. While the documentation technique is used for collecting or collecting secondary data in the form of documents. The instruments used in this study were structured interview guidelines and documents. The unit of analysis for this research is the role of village officials as the person in charge of managing village funds in Sungai Asam Village, Karang Intan District, Banjar Regency. The informants in this study were the Head of Sungai Asam Village and the community who were the subjects or objects of empowerment. This research was conducted in Sungai Asam Village, Karang Intan District, Banjar Regency.

\section{RESULTS AND DISCUSSION}

Based on Law Number 6 of 2014, the role of the village head is as the holder of village management power in planning, implementing, monitoring, and evaluating the use of village funds. Based on the results of interviews with village heads, the implementation of the coordination function between village heads and village officials in the use of village funds has been maximal and quite good. This can be seen from the implementation of the entire program of activities in the Sungai Asam Village Government Work Plan. This proves that the coordination function is running well. Apart from the coordination function with village officials, the coordination of the village head with the community as beneficiaries of the activity did not experience any significant problems. There is almost no miscommunication with the village community because of the leadership style of the village head who is communicative and often goes to the field so that there is no distance between village officials and the community. This is supported by the results of interviews with the community as beneficiaries of village funds that the village head's leadership is good enough based on performance achievements in implementing all program activities. Good village head leadership is also supported by the transparency and accountability of village fund management by village officials through access that can be seen by the community such as banners, announcement boards, and so on. The empowerment program carried out in Sungai Asam village is training in making sasirangan cloth, stunting counseling, posyandu, youth organizations, and so on. The entire community empowerment program in Sungai Asam village based on information and information from the community has been carried out optimally and has had a positive effect and a very significant impact on the empowerment of the community in Sungai Asam Village. The community 
Dedi Nurmadi et al., Saudi J Econ Fin, Feb, 2021; 5(2): 76-79

hopes that this activity can be maintained and continued for years to come.

The Village Fund Program is designed to empower the community by adopting a people-centered development approach towards sustainable development. This program also applies the principles of cooperation, community self-reliance, and community participation to realize development from below by empowering the poor, so that they understand the various potentials they have that can be utilized to carry out centralized development. Peter [2] states that active community participation is participation that sees community involvement starting from the stages of decision making, implementing decisions, enjoying results, and evaluating. Through the village fund program, the development paradigm has started to shift from a top-down to bottom-up development paradigm, from conventional to participatory and it is hoped that the capacity of the community can increase both individually and in groups in solving various problems related to efforts to improve the quality of life, independence, and welfare. As stated by Rappaport [3], empowerment is defined as a process, a mechanism; in this case, individuals, organizations, and their communities become experts on the problems they face. Sungai Asam villagers have been able to run this system even though it is not optimal.

Based on the results of the study, it was shown that in the program socialization activities at the planning stage, community involvement was only limited to passive participation. Where the community functions more as listeners and provides voice support when proposals have been obtained which are the needs of the group and society at large. Although the presence of the community in the socialization forum serves more as a listener, there are still several community members present who express their opinions about their real needs and strategic plans in overcoming poverty. So it can be said that community involvement in controlling village fund activities is still minimal. The community generally leaves supervision and control to the BPD, community leaders, and village officials. Whereas the task of supervision and control is a shared task of all elements of the Sungai Asam Village community. Sungai Asam village community participation was seen to be more active in evaluating the performance of the TPK (Implementation Team) for village funds. This is not in line with the opinion of Manulang [4] that the ideal community involvement starts from the stages of decision making, implementing decisions, enjoying results, and evaluating. Tjokroamidjojo [5] also states that participation is defined as participation or participation in the development process, both in planning, implementing, enjoying results, and evaluating.
The presence of community workers at village assistants is very necessary for carrying out the basics of community empowerment to facilitate, guide, and direct the community who is the target of village fund activities. However, in reality, the assistance of activities carried out by the facilitators of Sungai Asam Village is not optimal. They argued that the limited manpower and the wide coverage of the areas that were the target of the activities were the main obstacles so that the assistance of Sungai Asam village was not maximal. It is felt that the assistance provided by village assistants has not been able to build an understanding of the final results of the village fund program that they want to target. The village assistant stated that the limited level of education of the people of Sungai Asam Village, which was still low, was a problem in itself. The high level of understanding and participation of the Sungai Asam village community amid low education is a separate measure of success for village assistants who have been able to guide the village community with all its limitations to become an empowered community. This is where the very strong role of the facilitator to guide and direct the community to become part of the village fund activities. Community participation in the implementation of village fund activities that have been carried out in Sungai Asam Village through the village fund program has reached actual participation. Where the community is involved in the process of empowerment activities and makes their own decisions. Abduk Wahab [6] states that the effects of the policy include two things, namely positive and negative results, both those expected by policymakers and those that are not expected both primary and secondary. The village fund program is aimed at poor community groups both in rural areas to be empowered to be more advanced, independent, and sustainable so that it will have positive and beneficial impacts and changes for rural communities, especially in Sungai Asam Village, Karang Intan District.

\section{CONCLUSION}

Based on the results of the research and analysis carried out in this study, it can be concluded that the role of village officials, namely the Village Head / Pambakal in the efforts to empower the community of Sungai Asam Village, Karang Intan District, especially in the management of village funds is already good. This is proven by the number of community empowerment programs that are running well and the positive community response to the performance of the Sungai Asam village head.

\section{REFERENCE}

1. Mukhtar, S. (2004). Pengantar Metodologi Penelitian Sosial, Pustaka FISIP Banjarmasin.

2. Peter, E. (1996). Government Action, Social Capital and Development: Reviewing the Evidence on Synergy, World Development. 
Dedi Nurmadi et al., Saudi J Econ Fin, Feb, 2021; 5(2): 76-79

3. Rappaport. (1987). "Terms of Empowerment/Exemplars of Prevention: Toward a Theory for Community Psychology", American Journal of Community Psychology

4. Manulang, M. (1996). Dasar-Dasar Manajemen. Jakarta: Ghalia Indonesia.
5. Tjokroamidjojo, B., (1996). Perencanaan Pembangunan, Cetakan Kelima, Penerbit PT Toko Gunung Agung: Jakarta, 1996.

6. Wahab, S.A. (1997). Analisis Kebijaksanaan Dari Formulasi ke Implementasi kebijaksanaan Negara, Bumi Aksara, Jakarta. 